\title{
Parasites Status of Village Chickens (Gallus gallus domesticus) in Selected Communities in Yenagoa Local Government Area of Bayelsa State, Nigeria
}

\author{
Kingsley Elele', Ebenezer Amawulu² ${ }^{*}$, Kurokeyi Prosper Eniyekedidei ${ }^{1}$ \\ ${ }^{1}$ Department of Biology, Faculty of Natural and Applied Sciences, Ignatius Ajuru University of Education, Port Harcourt, Rivers \\ State, Nigeria \\ ${ }^{2}$ Department of Biological Sciences, Faculty of Sciences, Niger Delta University, Wilberforce Island, Bayelsa State, Nigeria \\ Email: *ebenezeramawulu@gmail.com
}

How to cite this paper: Elele, K., Amawulu, E. And Eniyekedidei, K.P. (2021) Parasites Status of Village Chickens (Gallus gallus domesticus) in Selected Communities in Yenagoa Local Government Area of Bayelsa State, Nigeria. Open Journal of Applied Sciences, 11, 230-238.

https://doi.org/10.4236/ojapps.2021.112016

Received: January 3, 2021

Accepted: February 23, 2021

Published: February 26, 2021

Copyright $\odot 2021$ by author(s) and Scientific Research Publishing Inc. This work is licensed under the Creative Commons Attribution International License (CC BY 4.0).

http://creativecommons.org/licenses/by/4.0/

\begin{abstract}
Parasites constitute a major obstacle to poultry production, leading to significant losses in many poultry farms. This study investigated the parasites status of village chicken (Gallus domesticus) collected from selected communities in Yenagoa Local Government Area of Bayelsa State Nigeria, during January to March 2020. A total of 35 birds were collected from 5 communities: Igbogeni, Tombia, Agudama, Akenfa and Opolo to assess their parasitic status. The procession of the chicken and the identifications of both ecto and endo parasites followed standard techniques. From the results, the prevalence of the ecto parasites and the endo parasites in the chickens were $85.71 \%$ and $88.57 \%$ respectively. The ectoparasites species in order of increasing frequency were Lice (37.65\%), Fleas (32.94\%), and Mites (29.41\%). Mixed infection of lice \& fleas accounted for $34.12 \%$. The prevalence of endo parasites was: Nematode (71.59\%) and Cestode (28.41\%) respectively. The species specific prevalence of the endo parasites encountered were Ascaridia galli (44.4\%), Heterakis gallinarum (22.2\%), Capillaria spp. (33.3\%), Davainea proglottina (56\%), Raillientina spp. (44\%) respectively. This present study has provided an insight into parasitic infection of domestic birds across communities in Yenagoa Local Government Area of Bayelsa State Nigeria and recommended that an intensive health education on their public health implications in the spread disease causing pathogens among humans be carried out.
\end{abstract}

\section{Keywords}

Gallus domesticus, Ectoparasites, Endoparasites, Yenagoa 


\section{Introduction}

Village chicken (Gallus domesticus) is the major species in the rural poultry sub-sector in Africa [1] [2]. Traditionally, in some parts of Asia and Arica, village chickens are kept in the backyard by housing them in locally made hut in the night and allowing them to scavenge for food during the daytime [3] [4].

In Nigeria, village chicken production is the most established profit making business compared to other domesticated animal species [5]. Given its protein demand, chicken production is the pillars in which the future of improved protein supply and nation's economy rests [4] [6]. However, as important as poultry birds are to human dietary requirements, its production is limited by several factors, such as poor management, malnutrition, lack of bio-security, poor housing, poor veterinary services and parasite infestation [6]. Parasitic infestations manifest as late maturity, reduce egg output, induce emaciation, anaemia and death [7] [8]. Common among the poultry parasites are Mites, Gnats, Fleas, Lice and Ticks, Helminthes and Protozoa [9]. Parasites are considered as a major obstacle in poultry production, causing significant losses in many poultry farms. Studies haves shown that $100 \%$ of village chicken are infected with one or more parasites [10]. Other studies reported that, $71.3 \%$ prevalence of parasites was recorded among free range birds in the Southeastern part of Nigeria [6], 87.8\% prevalence of helminth infection was recorded in Bauchi state [11], 81.5\% of parasites were recorded in Kaduna State [12]) and 96.8\% in Nsukka region of South Eastern Nigeria [4] while in Sokoto Metropolis, Bala, et al. [13] recorded four ectoparasites in the order of magnitude; Lice (27.5\%), Mites (17.5\%), Ticks (14.4\%), Fleas (10.6\%). The basic pre-requisite to reduce the menace of parasites burden in poultry birds in a local farm is to identify infested farm and characterize the type of parasitism in the birds (4). However, there is a paucity of information of parasites infestation in village chickens across communities in Yenagoa Local Government Area of Bayelsa State. This is the first study to assess the parasites burden of village chicken in selected communities in Yenagoa Local Government Area. The result of this study shall establish the public health implications of parasites infected chickens and call for public health intervention.

\section{Materials and Methods}

\subsection{Study Area}

Yenagoa $\left(5^{\circ} 02^{\prime} \mathrm{N} 6^{\circ} 20^{\prime} \mathrm{E}\right)$ is the capital of Yenagoa Local Government Area and Bayelsa State. Yenagoa Local Government Area has an area of $106 \mathrm{~km}^{2}$. The study communities for this study is shown in Figure 1. The communities are: Igbogeni, Tombia, Agudama, Akenfa and Opolo. Agriculture and subsidiary farming (Plantain, Banana production, fishing, and livestock including poultry production are the major occupations of the people.

\subsection{Ethical Consideration}

Verbal approval from the house hold head having local chicken houses. The age 


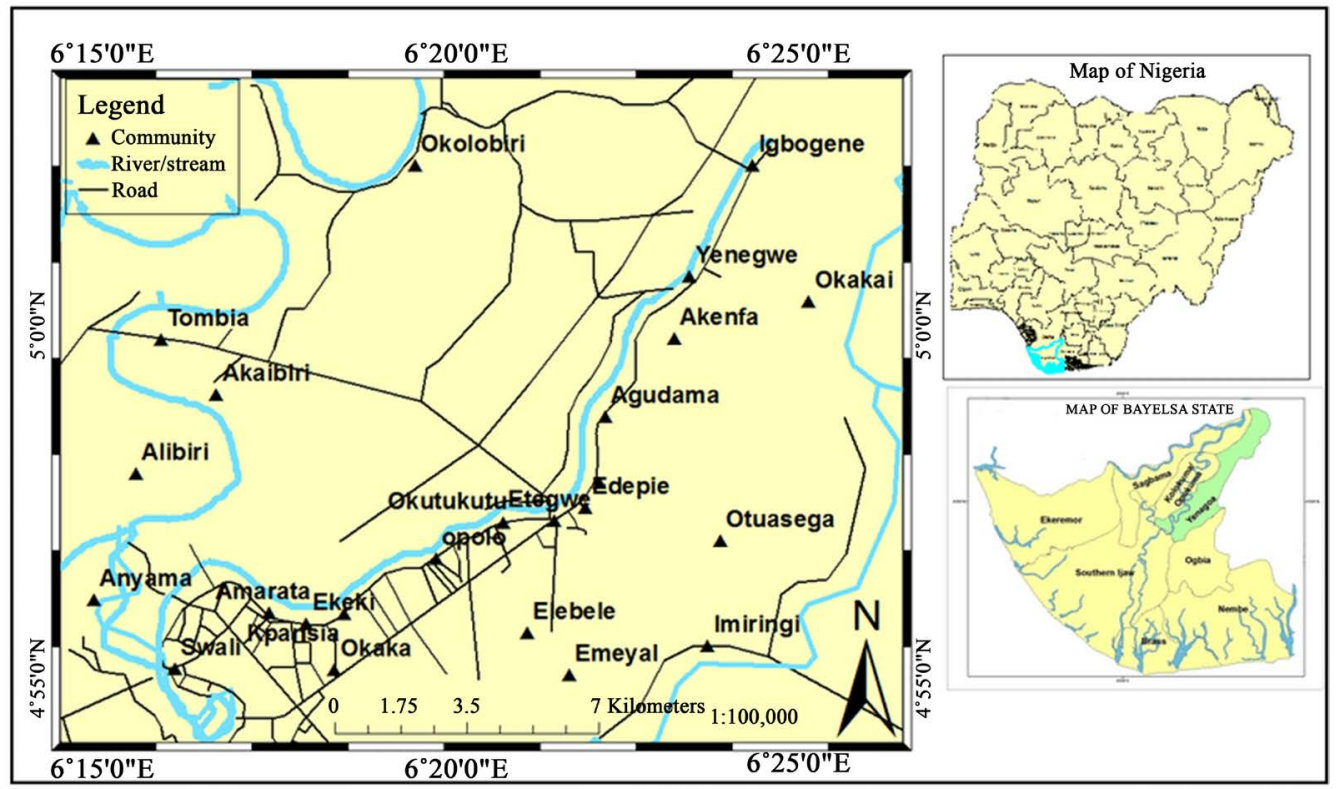

Figure 1. Map showing the study communities (source: google map).

and the weight of the chicken was sought for. The price tag for each of the chicken was fixed.

\subsection{Inclusion Criteria}

The chicken to be selected has no sex restriction. However, birds of the same weight and age were all included for the study. The age of the chicken was sought from the househlod head and by their group movement.

\subsection{Sample Collection}

Chickens were collected from households across the 5 communities enlisted for the study during January, 2020 to March, 2020. The birds were randomly collected irrespective of their sexes. The selected birds were priced and bought. A minimum of 7 birds was selected from each community, making a total of 35 birds. Prior to examination, the chicken were collected early in the morning, from each of the selected chicken house in a sterilized cellophane bag properly perforated to allow maximum ventilation.

\subsection{Examination and Identification of Parasites}

The procession and examination of the birds for ectoparasites assessments followed standard techniques in Angyiereyiri, et al. [14]. Each of the sampled bird was placed on a white sheet of paper. The bird was examined for ectoparasite by ruffling the feathers with fine blunt toothed brushe. Ectoparasites that fell on the paper were collected and preserved in 70\% ethanol. The morphological identification of parasites followed keys in Soulsby [15].

Fecal samples were extracted from the cloaca of the birds using a sterilized swab stick and preserved in a sample bottles containing $10 \%$ formalin and la- 
belled accordingly to correspond with the record of the ectoparasite of each chicken. The procession of fecal sample for parasite examination followed standard concentration method in Cheesbrough [16]. A-2 g weight of the fecal sample was collected with a spatula from the sample bottle and introduced into an empty sample bottle containing normal saline and stirred to make a fecal suspension. The solution was filtered into a clean and empty sample bottle with a sieve. The process was repeated twice. A-3 $\mathrm{ml}$ of normal saline and the final filtrate was mixed, stirred and allowed to stand for about 15 seconds. A-3 ml of ether and the final solution was mixed gently. The solution was then centrifuged at $3000 \mathrm{rpm}$ for 5 minutes and the supernatant was decanted. Another $3 \mathrm{ml}$ of normal salinewas mixed with the sediments, stirred with a glass rod and centrifuged again for the second time at $2000 \mathrm{rpm}$ for 3 minutes. The supernatant was carefully decanted and preserved in sterilized bottle. The specimen was collected with a pipette into a grease free microscopic slide and stained with a drop of lugol's iodine. The presence of parasite was confirmed by a microscopist using $\times 100$ oil immersion.

\subsection{Data Analysis}

Data entry was done using Microsoft excel and analysis was done using the SPSS software version 20. Descriptive statistics using simple percentages were employed to calculate the propertion of parasites recover from each bird across the communities. Relationship parasites burden across study communities was analysed ANOVA at confidence level of $p=0.05$.

\section{Results and Discussion}

The study of 35 chickens recorded $85.7 \%$ and $88.57 \%$ prevalence rates of ectoparasites and endoparasites respectively across 5 communities as shown in Figure 2. Multiple parasitism accounted for $100 \%$ of all the chickens examined. The differences of the parasites infestation were significant $(T=0.784421, p<0.05)$. The community specific prevalence of parasites in the chicken is shown in (Figure 3). The ectoparasites were more prevalent among the chickens in Tombia and Opolo communities while endoparasites were more prevalence among the chickens in Igbogene and Akenfa communities. The prevalence was the same in Agudama community. When the Ectoparasiteswere pooled across location, the order of frequency are Lice (37.65\%), Fleas (32.94\%) and Mites (29.41\%). Mixed infestation, of lice \& fleas accounted for $34.12 \%$. Differences was not significant $(\mathrm{T}=3.315332, \mathrm{p}>0.05)$ (Table 1$)$. Five endoparasites in two genera were identified. They are nematodes $(71.59 \%)$ and cestodes $(28.41 \%)$ respectively. Nematodes species recorded were Ascaridia galli (44.4\%) Heterakis gallinarum (33.3\%) and Capillaria spp. (22.2\%) respectively. The prevalence of cestodes; Davainea proglottina and Raillientina spp. was $56 \%$ and $44 \%$ respectively. Differences was significant $(\mathrm{T}=0.029092, \mathrm{p}<0.05)$. Detail is shown in Table 2.

Village chickens in all the five communities in Yenagoa Local Government 


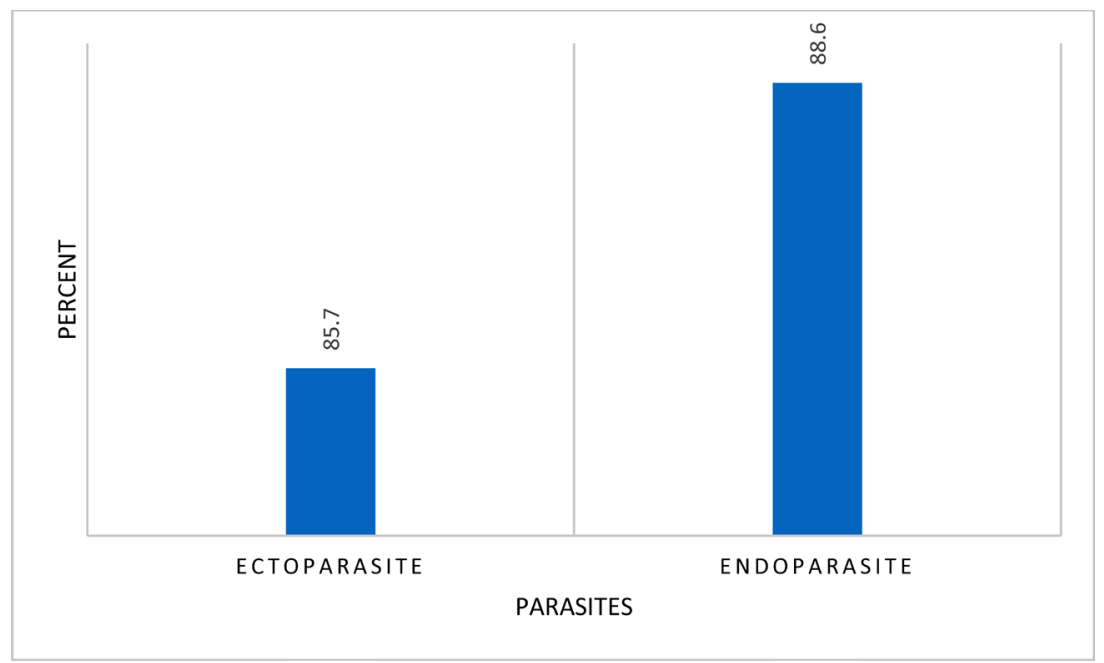

Figure 2. Prevalence of parasites in chickens across communities in YELGA during January, 2020 to March, 2020.

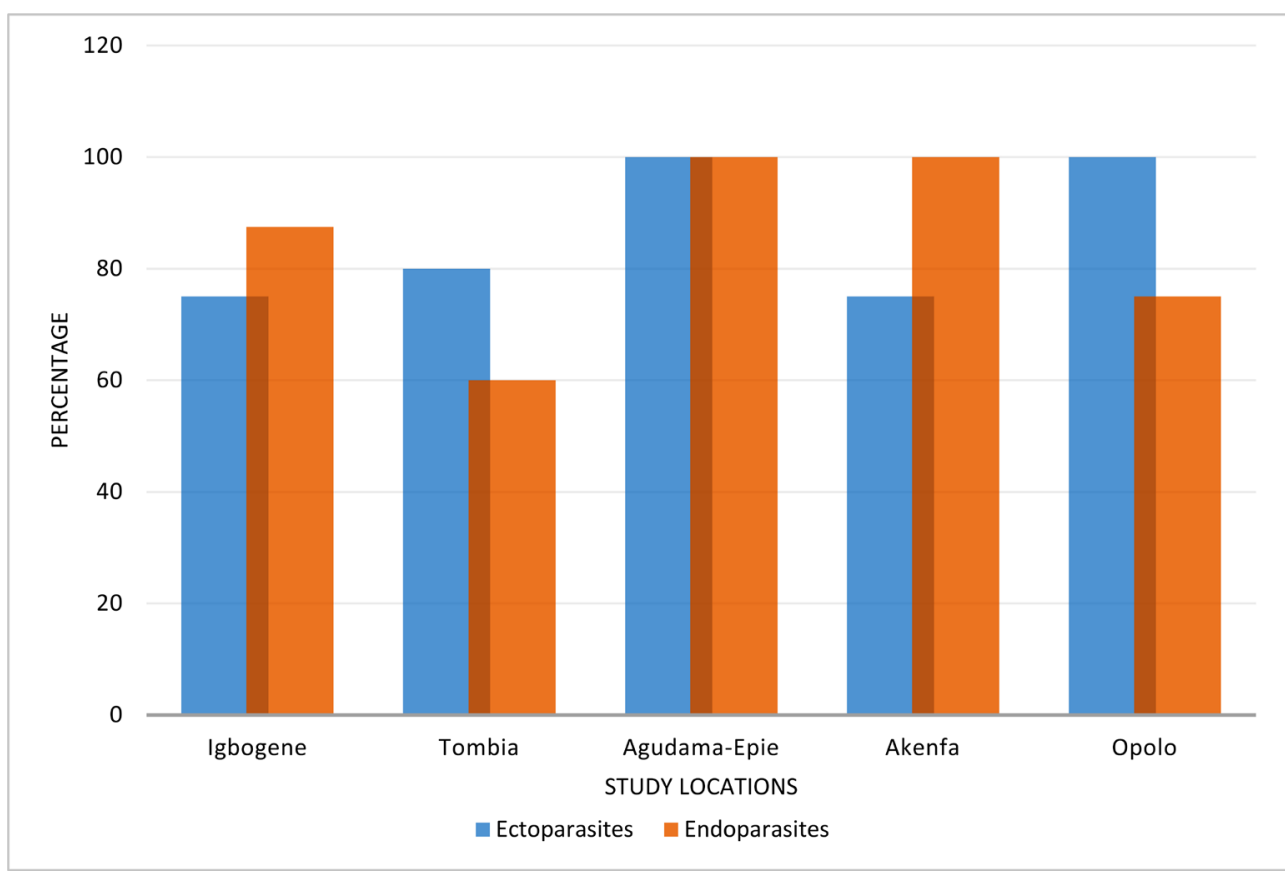

Figure 3. Location specific prevalence of ectoparasites and endoparasites.

Table 1. Specie-specific prevalence of ectoparasites in chickens across communities in YELGA during January, 2020 to March, 2020.

\begin{tabular}{ccc}
\multicolumn{3}{c}{$\mathbf{N}=\mathbf{3 5}$} \\
\hline Ectoparasite species & Number counted & Percentage counted \\
\hline Fleas & 28 & 32.94 \\
lice & 32 & 37.65 \\
mites & 25 & 29.41 \\
Total & $\mathbf{8 5}$ & 100 \\
Fleas + lice & 29 & 34.12 \\
\hline
\end{tabular}


Table 2. Specie-specific prevalence of endoparasites in chickens across communities in YELGA during January, 2020 to March, 2020.

\begin{tabular}{ccc}
\multicolumn{3}{c}{$\mathbf{N}=\mathbf{3 5}$} \\
\hline Endoparasite species & Number counted & Percentage counted \\
\hline Nematodes & 28 & \\
Ascaridia galli & 14 & 44.4 \\
Capillaria spp. & 21 & 22.2 \\
Heterakis gallinarum & 63 & 33.3 \\
Total & & 71.59 \\
Cestodes & 14 & 56 \\
Davainea proglottina & 11 & 44 \\
Raillientina spp. & 25 & 28.41 \\
Total & & \\
\hline
\end{tabular}

Area of Bayelsa State were commonly infested with wide range of parasites. This observation had been reported among village chickens elsewhere [6] [11] [17] [18].

The three ectoparasite; lice, mites and fleas encountered in this present study is an indication that the environment and the weather condition of the chickens were favorable for their proliferations and development [19]. More Lice (37.65\%) than the other ectoparasites were recovered. This observation agrees with the reports of Bala, et al. [13]. The higher prevalence of lice than the other ectoparasites highlight their ability to adapt favorably in both hot and humid weather conditions. The recovery of Fleas and mites in this present study has also been reported elsewhere [6]. However, Bala, et al. [13] and [20] gave a contrary report that fleas were the least occurring ectoparasites in chicken. The least prevalence of mites in the present study agrees with Nnadi and George [6].

More nematodes than cestodes were encounter in this present study. This difference is consistent with [17]. The higher prevalence of nematodes is an indication that the village chicken is more predisposed to nematodes infections. Most gastrointestinal parasites have direct life cycle pattern which correspond with the scavenging habit of the chicken. The lower cestode prevalence in this study is consistent with Marizvikuru and Patrick [17]). The Lower cestode prevalence may probably be associated with the environment. Cestodes require an intermediate host for transmission. The intermediate host may be rare in the environment to initiate transmission.

Studies in some part of Nigeria have shown a wide range of gastrointestinal parasite species in village chickens [11] [6]. The five species of gastro intestinal parasites recovered from chickens in this present study highlight the uncontrolled scavenging nature of these birds in different dumpsites, thereby exposing them to wide range of parasites [17]. Village chickens are less attended to by the veterinarian and are hardly treated or vaccinated may be responsible for parasite 
establishment.

Ascaridia galli, was more prevalent than other gastrointestinal parasites. Similar study reported that the higher prevalence of Ascaridia galli may be associated with their direct mode of transmission [21]. The implication of the wide range of parasites in the village chicken is that gastrointestinal parasites may lower the chicken feed efficiency and nutrient utilization, hence reducing the size of the birds and their protein contents [22] while the ectoparasites may cause discomfort, anaemia and loss of feathers in chicken, thus reducing the economic value of village chickens.

\section{Conclusion and Recommendation}

This present study has provided an insight into the parasitic status of village chickens across communities in Yenagoa Local Government Area of Bayelsa State Nigeria. There was a wide range of both ectoparasites and endoparasites recovered from the birds. These parasites were not only known to reduce size of birds, their protein contents and lower income value of the birds, but can be responsible for the initiation of zoonotic infections in humans. This study therefore calls for public health intervention.

\section{Acknowledgements}

We are grateful to the household head whose house the chickens were collected for the study. We are also grateful to the Biological Science laboratory staff of the Ignatius University, Rivers State.

\section{Conflicts of Interest}

The authors declare no conflicts of interest regarding the publication of this paper.

\section{References}

[1] Mafu, J.V. and Masika, P.J. (2003) Small-Scale Broiler Production by Rural Farmers in the Central Eastern Cape Province of South Africa. Fort Hare Papers, 121, 25-34.

[2] Kitalyi, A. (1988) Village Chicken Production Systems in Rural Africa Household Food Security and Gender Issues: FAO Animal Production and Health Papers 142. Publishing Management Group, FAO Information Division, Rome.

[3] Aini, I. (1990) Indegenous Chicken Production in South-East Asia. World s Poultry Science Journal, 46, 51-57. https://doi.org/10.1079/WPS19900010

[4] Food and Agriculture Organization of the United Nations (2011) Mapping Supply and Demand for Animal-Source Foods to 2030. Animal Production and Health Working Paper No. 2. http://www.fao.org/docrep/014/i2425e/i2425e00

[5] Heinke, H., Alexandra C. and Ludwig T. (2015) The Poultry Market in Nigeria: Market Structures and Potentials for Investment. International Food and Agribusiness Management Review, 18, 197-222.

[6] Nnadi, P.A. and George, S.O. (2010) A Cross-Sectional Survey on Parasites of Chickens in Selected Villages in the Subhumid Zones of South-Eastern Nigeria. Journal of Parasitology Research, 2010, Article ID: 141824. 
https://doi.org/10.1155/2010/141824

[7] Irungu, L.W., Kimani, R.N. and Kisia, S.M. (2004) Helminth Parasites in the Intestinal Tract of Indigenous Poultry in Parts of Kenya. Journal of the South African Veterinary Association, 75, 58-59. https://doi.org/10.4102/jsava.v75i1.452

[8] Phiri, I.K., Phiri, A.M., Ziela, M., Chota, A., Masuku, M. and Monrad, J. (2007) Prevalence and Distribution of Gastroinyestinal Helminthes and Their Effects on Weight Gain in Free-Range Chickens in Central Zambia. Tropical Animal Health and Production, 39, 309-315. https://doi.org/10.1007/s11250-007-9021-5

[9] Nnadozie, V.O. (1996) Prevalence of Ectoparasites of Ocal Chicken in Nsukka Area of Enugu State, Nigeria. University of Nigeria, Nsukka.

[10] Permin, A., Magwisha, H., Kassuku, A.A., Nansen, P., Bisgaard, M., Frandsen, F. and Gibbons, L. (1997) A Cross Sectional Study of Helminthes in Rural Scavenging poultry In Tanzania in Relation to Season and Climate. Journal of Helminthology, 71, 233-240. https://doi.org/10.1017/S0022149X00015972

[11] Yoriyo, K.P., Adang, K.L., Fabiyi, J.P. and Adamu, S.U. (2008) Helminth Parasites of Local Chickens in Bauchi State Nigeria. Science World Journal, 3, 35-37. https://doi.org/10.4314/swj.v3i2.51782

[12] Junaidu, H.I., Luka, S.A. and Mijinyawa, A., (2014) Prevalence of Fastrointestinal Helminth Parasites of the Domestic fowl (Gallus-Gallus domesticus) Slaughtered in Giwa Market, Giwa Local Government Area, Kaduna State, Nigeria. Journal of Natural Sciences Research, 4, 120-125.

[13] Bala, A.Y., Anka, S.A., Waziri A. and Shehu H. (2011) Preliminary Survey of Ectoparasites Infesting Chickens (Gallus domesticus) in Four Areas of Sokoto Metropolis, Nigerian Journal of Basic and Applied Science, 19, 173-180.

[14] Angyiereyiri, E.D., Sackey, L. and Bonu-Ire, M.S.T. (2015) Survey on Arthropod Ectoparasites on Goats and Domestic Fowls in Vunania, Navrongo, Ghana. Canadian Journal of Pure and Applied Sciences, 9, 3371-3377.

[15] Soulsby, E.J.L. (1982) Helminths, Arthropods and Protozoa of Domesticated Animals. Baillerie Tindall, London.

[16] Foreyt, WJ (2002) Verterinary Parasitology. Reference Manual, 5th Edition, Iowa State University Press, Ames.

[17] Marizvikuru, M. and Patrick, J.M (2011) Point Prevalence Study of Gastro-Intestinal Parasites in Village Chickens of Centabe Districtm South Africa. African Journal of Agriculture, 6, 2033-2138.

[18] Jegede, O.C., Asadu, I.A., Opara Obeta, S. and Olayemi, D.O (2015) Gastrointestinal Parasitism in Local and Exotic Breeds of Chickens Reared in Gwagwalada Guinea Savannah Zone of Nigeria. Sokoto Journal of Veterinary Sciences, 13, 25-30. https://doi.org/10.4314/sokjvs.v13i3.5

[19] Fabiyi, J.P. (1996) Association between Duration of Humid Season and Geographical Distribution of Patterns of Different Species of Chewing Lice (Mallophaga: Insecta) Infesting Domestic Chickens in Nigeria. Journal of Parasitology, 82, 1034-1036. https://doi.org/10.2307/3284220

[20] Okoroafor, P.O. and Nzeako, S.O. (2014) Prevalence of Haemoparasites of Cattle from Three Abattoirs in Ibadan Metropolis, Oyo State, Nigeria. International Journal of Scientific Research in Environmental Sciences, 297, 244-249.

[21] Ngongeh, L.A., Chiejina, S.N. and Lawal, A.I. (2004) Prevalence of Gastrointestinal Helminth Infections in Slaughtered Chickens Reared in the Nsukka Area of Enugu State, Nigeria. IOSR Journal of Agriculture and Veterinary science, 7, 51-54. https://doi.org/10.9790/2380-071135154 
[22] Magwisha, H.B., Kassuku, A.A., Kyvsgaard, N.C. and Permin, A. (2002) A Comparison of the Prevalence and Burdens of Helminth Infections in Growers and Adult Free-Range Chickens. Tropical Animal Health and Production, 34, 205-214.

https://doi.org/10.1023/A:1015278524559 